\title{
The SOLA Award in 2016
}

The Editorial Committee of Scientific Online Letters on the Atmosphere (SOLA) gives The SOLA Award to outstanding paper(s) published each year. I am pleased to announce that The SOLA Award in 2016 is going to be presented to the paper by Dr. Toru Adachi et al., entitled with "Rapid volumetric growth of misocyclone and vault-like structure in horizontal shear observed by phased array weather radar" (Adachi et al. 2016).

Misocyclones are vertically oriented vortices with the horizontal scales from $40 \mathrm{~m}$ to $4 \mathrm{~km}$ and have a potential for wind disasters. This study investigates the rapid evolution of misocyclones that developed in the northern part of Osaka on 25 August 2013 by conducting high-temporal resolution observations with a phased array weather radar (PAWR). The PAWR observation showed that the top altitude of the misocyclones, developed in a horizontally sheared environment, was shown to rapidly grow from $1.2 \mathrm{~km}$ to $1.8 \mathrm{~km}$ height in two minutes and that the misocyclones gained a vault-like structure in the next two minutes. The analysis indicated that shear instability plays a role in the evolution of the misocyclones through stretching of vertically oriented vortices.

This study is highly evaluated in demonstrating an observational evidence that the structure of misocyclones rapidly changes within a few minutes. Such a rapid growth was captured for the first time with a PAWR that can observe three-dimensional structure of precipitation and wind at the 30-second interval. Because misocyclones have a potential for wind disasters, it is important to understand the evolution of misocyclones and the resulting wind gusts. Furthermore, misocyclones sometimes play a role in initiating strong convection, and therefore, monitoring misocyclones at high-temporal resolutions should contribute to advancing now-casting of severe weather. Therefore, the Editorial Committee of SOLA highly evaluates the excellence of the authors' study.

Tetsuya Takemi

Chief Editor

30 January 2017

\section{References}

Adachi, T., K. Kusunoki, S. Yoshida, H. Inoue, K. Arai, and T. Ushio, 2016: Rapid volumetric growth of misocyclone and vault-like structure in horizontal shear observed by phased array weather radar. SOLA, 12, 314-319, doi: 10.2151/sola.2016-061. 